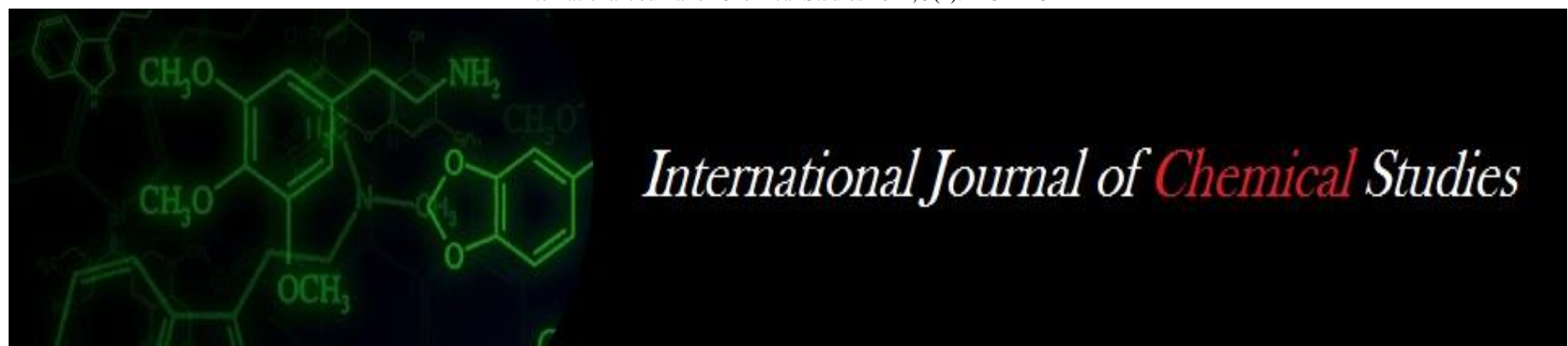

P-ISSN: 2349-8528

E-ISSN: 2321-4902

www.chemijournal.com

IJCS 2021; 9(1): 1282-1284

(C) 2021 IJCS

Received: 17-10-2020

Accepted: 30-12-2020

Diksha Nautiyal

School of Agriculture Sciences,

Shri Guru Ram Rai University,

Dehradun, Uttarakhand, India

\section{AK Saxena}

School of Agriculture Sciences, Shri Guru Ram Rai University, Dehradun, Uttarakhand, India

Priyanka Bankoti

School of Agriculture Sciences, Shri Guru Ram Rai University, Dehradun, Uttarakhand, India

\section{Response of soluble synthetic fertilizers with varying concentration of liquid manures on growth and yield of mustard at Dehradun district of Uttarakhand}

\author{
Diksha Nautiyal, AK Saxena and Priyanka Bankoti
}

DOI: https://doi.org/10.22271/chemi.2021.v9.i1r.11401

\begin{abstract}
This study was performed at Agriculture research farm of Shri Guru Ram Rai University, Dehradun, (U.K), India. In order to investigate the effect of soluble nutrients with varying concentration of liquid manure on growth parameters, various yields and yield attributes of mustard crop, field experiment was carried out during summer season (2019-20) at Research Block of S.G.R.R. University, Dehradun Uttarakhand. The layout of experimental field was laid randomized block design (RBD) with 7 treatments and 3 replications. Consisting of $\mathrm{T}_{1}$ (Control), $\mathrm{T}_{2}$ RDF (NPK 12:32:16), $\mathrm{T}_{3}$ (Vermiwash) @ 5\%, T4 (cow urine) @ 5\%, T5 (vermiwash @ 5\% +cow urine @ 5\%), T6 (N: P: K (19:19:19) Soluble @ 2\%+cow urine @ 5\%)), T7 (N: P: K (19:19:19) Soluble @ 2\% +vermiwash @5\%). All treatments were applied two times at 20 days interval. The results indicated that among all the treatments, $\mathrm{T}_{7}(\mathrm{~N}: \mathrm{P}: \mathrm{K}$ (19:19:19) Soluble @ 3\% +vermiwash @5\%), overall was found best for farmer point of view with respect to plant height $(113.3 \mathrm{~cm})$, number of seeds/siliqua $(18.3)$, test weight $(1000$-seed weight) $(4.36 \mathrm{gm})$, seed yield $(1515.9 \mathrm{~kg} / \mathrm{ha})$, and stover yield $(1851.81 \mathrm{~kg} / \mathrm{ha})$ at harvest and net return $(51407.5$ rs/ha), gross return (70787.5), B:C ratio (2.65). Based on present investigation, it can be concluded that the combination of both soluble fertilizer with liquid manure are applied that improved yield and yield attributes of mustard crop under present agro-climatic conditions.
\end{abstract}

Keywords: Soluble, synthetic, liquid, manures, mustard

\section{Introduction}

Mustard and rapeseed (Brassica juncea L Czern \& Coss, rapa) is an important oilseed crop belonging to family cruciferous (Syn. brassicacae). Rapeseed-mustard is the third most important edible oilseed crop in India after soybean and groundnut. Mustard is a cool season crop, which requires temperature range of 10- 25 degree centigrade. Mustard is generally grown as rainfed condition and moderately tolerant to soil acidity, it required well drained soil having $\mathrm{pH}$ near to neutral. It has low water requirement $(240-400 \mathrm{~mm})$ which fits well under rain fed cropping system. India is the third largest producer of rapeseed-mustard (Piri et al. 2011) occupying 6.23 million hectares area with 9.34 million tonnes production, but the average yield of rapeseed-mustard in India is only $1499 \mathrm{~kg} / \mathrm{ha}$ (Directorate of Economic \& Statistics, Gov., of India 2018-19) due to the lack of optimum use of nutrients and improper management. Rapeseed -mustard are the major Rabi oilseed crops of India and stand next to groundnut in the oilseed economy. The contribution of rapeseed-mustard to the total oilseed production in India is 26.0 percent. Indian mustard (Brassica juncea) is predominantly cultivated in the states of Rajasthan (38.07\%), Uttar Pradesh (12.08\%), Haryana (9.78\%), Madhya Pradesh (12.49\%), and West Bengal (9.87\%). Domestic production of edible oils meets only $50 \%$ of the total requirements, while rest is imported. Huge gap between the consumption and domestic production of edible oils can be filled up by increasing the area under oilseed crops like rapeseed and mustard, sunflower and soybean or increasing production per unit area. 


\section{Material and Methods}

The present investigation entitled "Response of soluble synthetic fertilizer with varying concentration of Liquid Manures on Growth and Yield Attributes of Indian mustard Brassica juncea L." in Dehradun Valley was carried out during Rabi season of 2019 - 2020 in the Agricultural Farm of Shri Guru Ram Rai University, Dehradun, Uttarakhand, India. It is located in the north western region of Uttarakhand at an altitude of $450 \mathrm{~m}$ above mean sea level

(MSL) and 3088 square kilometer in size. Geographically, the location of Dehradun is in between 29 58' and 31 2'30" North latitude and 77 '34'45" and $7818^{\prime} 30^{\prime \prime}$ "east longitudes.

The climate of Dehradun is humid subtropical. Summer temperatures can reach up to $44^{\circ} \mathrm{C}$ for a few days and a hot wind called Loo blows over North India. Winter temperatures are usually between 1 and $20^{\circ} \mathrm{C}$ and fog is quite common in winters like plains. Although the temperature in Dehradun can reach below freezing during severe cold snaps, this is not common. During the monsoon season, there is often heavy and protracted rainfall.

The soil of experimental site is classified as 'sandy loam' with characteristics as deep, well drained, coarse loamy cover over fragmental soils and of medium fertility. Total five soil samples were taken from upper $(0-15 \mathrm{~cm})$ layer of the soil and mixed properly from different sites of the field. After proper mixing of the soil, a representative sample was taken for its physiochemical process. A composite soil sample was prepared and analyzed separately for different physiochemical characteristics of the soil

The analysis revealed that the soil of the experimental site was Sandy loam in texture poor in organic matter, low in available nitrogen, medium in available phosphorus and Potassium contents with neutral in reaction and normal in electrical conductivity.

The experimental site having neutral $\mathrm{pH}$ and experiment was laid out in completely Randomized block design (RBD). The experiment was replicated thrice with 7 treatments viz., $\mathrm{T}_{1}$ (Control), $\mathrm{T}_{2}$ RDF, $\mathrm{T}_{3}$ (Vermiwash) @5\%, $\mathrm{T}_{4}$ (cow urine) @5\%, $\mathrm{T}_{5}$ (vermiwash @5\% +cow urine @ 5\%), $\mathrm{T}_{6}(\mathrm{~N}: \mathrm{P}: \mathrm{K}$ (19:19:19) Soluble @ 2\%+cow urine @5\%), T $(\mathrm{N}: \mathrm{P}: \mathrm{K}$ (19:19:19) Soluble@ @ +vermiwash @5\%). All the treatments were applied two times in the crop period first all treatments applied at 20 DAS and second application was 20 days after the first application (i.e. 40 DAS)

The spacing of mustard crop was $45 \times 15 \mathrm{~cm}$. Gross plot size was $9.2 \mathrm{~m}(4 \mathrm{mx} 2.3 \mathrm{~m})$ and net plot size was $6 \mathrm{~m}(3 \mathrm{mx} 2 \mathrm{~m})$. Total numbers of plots were 21

\section{Result and Discussion \\ Plant height}

Observations on the plant height were recorded at 30, 45 and 60 DAS and at harvest and the data were statistically analyzed. The mean values have been presented in Table 1. At harvest stage, maximum height recorded under $\mathrm{T}_{7}(113.30$ $\mathrm{cm})$ i.e. soluble NPK 19:19:19 (3\%) + vermiwash $(5 \%)$ followed by soluble NPK 19:19:19(2\%)+ cow urine@(5\%) $\mathrm{T}_{6}$ $(101.10 \mathrm{~cm}), \mathrm{T}_{2}(98.30 \mathrm{~cm}), \mathrm{T}_{5}(94.13 \mathrm{~cm}), \mathrm{T}_{3}(90.90 \mathrm{~cm}), \mathrm{T}_{4}$
$(85.06 \mathrm{~cm})$, and least height recorded on control plots i.e. $\mathrm{T}_{1}$ $(75.86 \mathrm{~cm})$.

\section{Number of leaves per plant}

The data on the number of leaves per plant at different stages of growth have been summarized and presented in Table 2. Number of leaves per plant increased with advancement in crop age up to 60 days of sowing. Differences in number of leaves due to different treatments were significant at all the stages of crop growth. At 60 DAS, the maximum number of leaves per plant was obtained under $\mathrm{T}_{5}(49.70)$, followed by $\mathrm{T}_{7}$ (45.20), $\mathrm{T}_{6}$ (40.60), $\mathrm{T}_{2}$ (34.06), which was significantly at par with $\mathrm{T}_{3}$ (33.93), $\mathrm{T}_{4}$ (32.13) and least number of leaves were observed under $\mathrm{T}_{1}(26.23)$.

\section{Seed yield}

The grain yield differed significantly due to addition of different combinations of organic and inorganic fertilizers treatments. Treatment $\mathrm{T}_{7}$ (soluble N P K 3\%+vermiwash 5\%) though recorded significantly highest grain yield (1516.02 $\mathrm{kg} / \mathrm{ha}$ ). Followed by $\mathrm{T}_{5}$ (cow urine $5 \%+$ vermiwash $5 \%$ ) recorded (1203.94 kg/ha). Similarly, $\mathrm{T}_{6}$ recorded yield (1032.04 kg/ha) followed by $\mathrm{T}_{2}(933.32 \mathrm{~kg} / \mathrm{ha})$, followed by $\mathrm{T}_{4}$ (824.68) which was similar to $\mathrm{T}_{3}$ (vermiwash $5 \%$ ) recorded $(824.65 \mathrm{~kg} / \mathrm{ha})$. Minimum yield recorded under $\mathrm{T}_{1}(666.60$ $\mathrm{kg} / \mathrm{ha})$.

\section{Stover yield}

A close examination of data on straw yield from the Table 3. Among all the treatments, $\mathrm{T}_{7}$ produced significantly higher straw yield $(1851.85 \mathrm{~kg} / \mathrm{ha})$ than other treatments. Further, treatment $\mathrm{T}_{5}$ gave $(1461.72 \mathrm{~kg} / \mathrm{ha})$ similar to $\mathrm{T}_{6}(1421.23$ $\mathrm{kg} / \mathrm{ha})$ then $\mathrm{T}_{3}(1170.33 \mathrm{~kg} / \mathrm{ha})$. Followed by $\mathrm{T}_{2}(1081.48$ $\mathrm{kg} / \mathrm{ha})$ and $\mathrm{T}_{4}(1066.65 \mathrm{~kg} / \mathrm{ha})$. Control $\left(\mathrm{T}_{1}\right)$ recorded lowest straw yield (1041.93 kg/ha) among all the treatments.

\section{Biological yield}

Data on Biological yield was calculated on the basis of grain and straw yield and the Mean data have been presented in Table 3 . Among all the treatments, $\mathrm{T}_{7}$ produced significantly higher biological yield $(3367.84 \mathrm{~kg} / \mathrm{ha})$ than other treatments. Further, Treatment $\mathrm{T}_{5}$ gave $(2665.64 \mathrm{~kg} / \mathrm{ha})$ followed by $\mathrm{T}_{6}$ $(2453.30 \mathrm{~kg} / \mathrm{ha})$ then $\mathrm{T}_{2}(2009.80 \mathrm{Kg} / \mathrm{ha}) . \mathrm{T}_{3}$ gives yield of $(1995.05 \mathrm{~kg} / \mathrm{ha})$ and followed by $\mathrm{T}_{4}(1891.30 \mathrm{~kg} / \mathrm{ha})$. Control $\mathrm{T}_{1}$ recorded lowest biological yield (1708.63 kg/ha) among all the treatments.

\section{Harvest index}

Data on the harvest index were gathered on the basis of grain yield and total biological yield and the mean data have been presented in Table 3. The non-significant differences were observed among the various weed control treatments for harvest index. However, treatment $\mathrm{T}_{2}$ had the highest harvest index value $(46.30 \%)$ followed by $\mathrm{T}_{5}(45.13 \%), \mathrm{T}_{7}(44.95 \%)$, $\mathrm{T}_{4}(43.70 \%), \mathrm{T}_{6}(42.80 \%), \mathrm{T}_{3}(40.90 \%)$. while the lowest harvest index was registered under $\mathrm{T}_{1}(39.09 \%)$.

Table 1: Plant height $(\mathrm{cm})$ at various stages of crop growth as influenced by different Treatments

\begin{tabular}{|c|c|c|c|c|c|}
\hline & \multirow{2}{*}{ Treatment } & \multicolumn{3}{|c|}{ Days After Sowing } & \multirow{2}{*}{ At Harvest } \\
\cline { 3 - 6 } & & $\mathbf{3 0}$ & $\mathbf{4 5}$ & $\mathbf{6 0}$ & \multicolumn{1}{c|}{7} \\
\hline $\mathrm{T}_{1}$ & Control & 25.46 & 56.26 & 68.26 & 75.86 \\
\hline $\mathrm{T}_{2}$ & RDF (NPK) & 28.00 & 61.73 & 85.53 & 98.30 \\
\hline $\mathrm{T}_{3}$ & Vermiwash @ (5\%) & 26.80 & 55.13 & 85.46 & 90.30 \\
\hline $\mathrm{T}_{4}$ & Cow urine @ (5\%) & 26.96 & 64.03 & 77.16 & 85.06 \\
\hline
\end{tabular}




\begin{tabular}{|c|c|c|c|c|c|}
\hline $\mathrm{T}_{5}$ & Vermiwash @ (5\%)+ cow urine @ (5\%) & 33.30 & 76.42 & 82.80 & 94.13 \\
\hline $\mathrm{T}_{6}$ & Soluble NPK 19:19:19 @ (2\%)+cow urine @ (5\%) & 31.23 & 76.56 & 93.70 & 101.10 \\
\hline $\mathrm{T}_{7}$ & Soluble NPK 19:19:19 @ (2\%)+ vermiwash @ (5\%) & 35.43 & 82.86 & 99.30 & 113.30 \\
\hline & $\mathrm{S} . \mathrm{Em} \pm$ & 1.32 & 1.19 & 0.95 & 0.86 \\
\hline & $\mathrm{CD}(\mathrm{P}=0.05)$ & 4.03 & 3.60 & 2.90 & 2.63 \\
\hline
\end{tabular}

Table 2: Number of leaves at various stages of crop growth as influenced by different treatments

\begin{tabular}{|c|c|c|c|c|}
\hline & \multirow{2}{*}{ Treatment } & \multicolumn{3}{|c|}{ Days After Sowing } \\
\cline { 2 - 5 } & Control & $\mathbf{3 0}$ & $\mathbf{4 5}$ & $\mathbf{6 0}$ \\
\hline $\mathrm{T}_{1}$ & RDF (NPK) & 8.16 & 14.86 & 26.23 \\
\hline $\mathrm{T}_{2}$ & Vermiwash @ (5\%) & 10.10 & 15.80 & 34.06 \\
\hline $\mathrm{T}_{3}$ & Cow urine @ (5\%) & 8.46 & 16.93 & 33.90 \\
\hline $\mathrm{T}_{4}$ & Vermiwash @ (5\%)+ cow urine @ (5\%) & 10.26 & 15.93 & 32.13 \\
\hline $\mathrm{T}_{5}$ & Soluble NPK 19:19:19 @ (2\%)+cow urine @ (5\%) & 15.23 & 24.40 & 49.70 \\
\hline $\mathrm{T}_{6}$ & Soluble NPK 19:19:19 @ (2\%)+vermiwash @ (5\%) & 14.26 & 18.80 & 40.60 \\
\hline $\mathrm{T}_{7}$ & $\mathrm{S.Em} \pm$ & 0.55 & 22.20 & 45.20 \\
\hline & $\mathrm{CD}(\mathrm{P}=0.05)$ & 1.68 & 2.85 & 0.74 \\
\hline & & & 2.60 & 26 \\
\hline
\end{tabular}

Table 3: seed yield, Stover yield and HI effected by different treatments

\begin{tabular}{|c|c|c|c|c|c|}
\hline & Treatment & Seed yield & Stover yield & Biological yield & H.I (\%) \\
\hline $\mathrm{T}_{1}$ & Control & 666.60 & 1041.93 & 1708.60 & 39.09 \\
\hline$T_{2}$ & RDF (NPK) & 933.30 & 1081.46 & 2009.80 & 46.30 \\
\hline $\mathrm{T}_{3}$ & Vermiwash @ (5\%) & 824.65 & 1170.30 & 1995.05 & 40.90 \\
\hline $\mathrm{T}_{4}$ & Cow urine @ (5\%) & 824.68 & 1066.65 & 1891.30 & 43.70 \\
\hline $\mathrm{T}_{5}$ & Vermiwash@ @ (5\%)+cow urine @ (5\%) & 1203.94 & 1461.72 & 2665.64 & 45.13 \\
\hline $\mathrm{T}_{6}$ & Soluble NPK 19:19:19 @ (2\%)+cow urine @(5\%) & 1032.04 & 1421.23 & 2453.30 & 42.80 \\
\hline \multirow[t]{3}{*}{$\mathrm{T}_{7}$} & Soluble NPK 19:19:19 @ (2\%)+ vermiwash @ (5\%) & 1516.02 & 1851.85 & 3367.80 & 44.95 \\
\hline & S.Em \pm & 99.50 & 111.90 & 136.24 & 3.50 \\
\hline & $\mathrm{CD}(\mathrm{P}=0.05)$ & 304.47 & 342.40 & 416.89 & 10.71 \\
\hline
\end{tabular}

\section{References}

1. Ahmad A, Abraham G, Gandotra N, Abrol YP, Abdin MZ. Nteractive effect 0 of nitrogen and sulphur on growth and yield of rape-seed-mustard (Brassica juncea L. Czern. and Coss. and Brassica campestris L.) genotypes. Journal of Agronomy and Crop Science 1998;181(4):193-199.

2. Anjani K, Srivastava RL, Patil VD. Crop improvement strategies in safflower \& linseed. Vegetables oil scenario Approached to meet the growing demands/ Ed by DM. Hetde, Hyderabad. I SOR 2009, 73-81.

3. Arora A, Vijay S, Das RR. Yield and oil quality of mustard as affected by rates of $\mathrm{N}$ and $\mathrm{S}$ in Inceptisols. Journal of Oilseeds Research 1994;11(2):273-276.

4. Chandra S, Ram D. Effect of integrated nutrient management on yield and nutrient use efficiency in mustard. Indian Journal of Fertilizers 2007;3(5):51-54.

5. Jahangir AA, Afroz RS, Latif A, Sarker MAM, Haq SMI. Response of mustard to $\mathrm{Mg}$ and $\mathrm{S}$ fertilization. Bangladesh Journal of Scientific and Industrial Research 2005;40(1/2):115-122.

6. Jat G, Sharma KK, Choudhary R. Effect of FYM and mineral nutrients on yield, content and uptake of nutrients in mustard. Ann. Agric. Res. New Series 2013;34(3):236240.

7. Patel GM, Patel BT, Dodia IN, Bhatt VK, Bhatt RK. Effect of sources and levels of sulphur on yield, quality and nutrient uptake of mustard (Brassica juncea L.) varieties in loamy sand soil. Journal of Soils and Crops 2009;19:30-35.

8. Subhash C. Effect of integrated nutrient management on yield and nutrient use efficiency in mustard (Brassica juncea L.). SAARC Journal of Agriculture 2007;5(2):93100.
9. Tripathi MK, Sumit, Chaturvedi S, DK Mahapatra BS. Yield performance and quality in Indian mustard (Brassica juncea) as affected by integrated nutrient management. Indian Journal of Agronomy 2010;55(2):138-142.

10. Punia BS, Porwal BL, Singh J. Varietal response of mustard to phosphorus fertilization on vertisols of Rajasthan. Annals of Biology 2002;18(1):47-48. 